\title{
A Teologia Política em Johann Baptist Metz: instrumento da Teologia Fundamental para uma práxis libertadora
}

Orientadora: Maria Clara Lucchetti Bingemer

Mestrando: José Diógenes Dias Gonçalves

Área de Concentração: Teologia Sistemático-Pastoral

Linha de Pesquisa: Religião e Modernidade

A pesquisa apresenta os principais temas do pensamento teológico-político de Johann Baptist Metz que servem de matriz para se repensar a responsabilidade e a práxis da teologia fundamental na sociedade. Tal pensamento não apenas aborda a questão do sofrimento humano, mas busca fundamentar o compromisso de uma teologia política da Igreja e do Cristianismo como um elemento fundante do projeto salvífico de Deus na pessoa de Jesus Cristo.

Palavras-chave: Johann Baptist Metz. Teologia Fundamental. Teologia Política. 